\title{
Pelatihan Penyusunan Perangkat Pembelajaran CAI-Kontekstual Matematika Bagi Guru-Guru SD
}

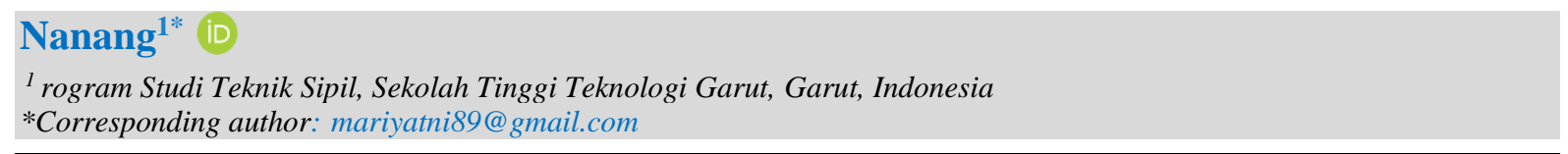

\begin{abstract}
Abstrak
Masih banyak guru yang melaksanakan pembelajaran secara konvensial dan tidak memanfaatkan multimedia secara optimal. Hal itu diakrenakan para guru tidak memiliki keterampilan pembelajaran berbasis komputer, sehingga jika guru-guru harus melakukan pembelajaran berbasis komputer maka mereka tidak memiliki kesanggupan untuk melaksanakannya. Pengabdian Program Kemitraan Masyarakat Stimulus (PKMS) ini bertujuan untuk meningkatkan kompetensi profesional guru secara berkelanjutan melalui pelatihan cara menyusun perangkat pembelajaran bagi guru-guru Sekolah Dasar. Kegiatan PKMS ini diikuti oleh guru-guru SD anggota PGRI sebanyak 45 guru yang dibagi ke dalam tiga kelompok. Metode pelaksanaan kegiatan mengadopsi pola pelaksanaan penelitian tindakan meliputi tiga tahapan kegiatan yaitu persiapan, pelaksanaan, dan evaluasi. Persiapan dilakukan dengan melakukan survey pendahuluan untuk melihat kondisi di lapangan mengenai pengembangan profesi guru. Pelaksanaan dilakukan dengan pelatihan, menggunakan metode ceramah yaitu dengan teknik presentasi, dilanjutkan dengan diskusi, tanya jawab, dan latihan. Evaluasi kegiatan dilakukan untuk masing-masing tahap dengan mengumpulkan dan menyimpulkan data dari masing-masing tahapan kegiatan. Hasil kegiatan PKMS ini diantaranya: (a) terbentuknya tiga kelompok kerja guru (KKG) berdasarkan letak lokasi SD; (b) adanya peningkatan pengetahuan dan keterampilan para guru tentang penyusunan perangkat pembelajaran dan pembuatan media pembelajaran matematika dengan pendekatan CAI-Kontekstual; (c) dihasilkan media (alat peraga) matematika untuk Siswa SD; (d) kemampuan guru dalam menggunakan media pembelajaran dalam pembelajaran matematika di kelas meningkat. Berdasarkan hasil pelatihan dapat disimpulkan bahwa peserta workshop telah menguasai materi yang dilatihkan, maka langkah selanjutnya masing-masing kelompok tersebut ditugaskan untuk menyebarkan pengetahuan dari hasil workshop keteman sejawatnya yang ada di sekolah terdekat dengan sekolah tempat mengajarnya.
\end{abstract}

Kata Kunci: CAI-Kontekstual, Matematika

\section{Abstract}

There are still many teachers who carry out conventional learning and do not use multimedia optimally. This is because teachers do not have computer-based learning skills, so if teachers have to do computer-based learning, they cannot do it. This Community Stimulus Partnership Program (PKMS) service aims to improve teacher professional competence on an ongoing basis through training on how to develop learning tools for elementary school teachers. This PKMS activity was attended by 45 elementary school teachers who were members of PGRI who were divided into three groups. The method of implementing the activities adopts an action research implementation pattern which includes three stages of activities, namely preparation, implementation, and evaluation. Preparation is done by conducting a preliminary survey to see conditions in the field regarding the development of the teaching profession. The implementation is carried out by training, using the lecture method, namely presentation techniques, followed by discussions, questions and answers, and exercises. Evaluation of activities is carried out for each stage by collecting and concluding data from each stage of activity. The results of this PKMS activity include: (a) the formation of three teacher working groups (KKG) based on the location of the primary school; $(b)$ an increase in the knowledge and skills of teachers regarding the preparation of learning tools and the manufacture of mathematics learning media with the CAI-Contextual approach; (c) produce mathematics media (props) for elementary students; (d) the ability of teachers to use learning media in learning mathematics in the classroom increases. Based on the results of the training, it can be concluded that the workshop participants have mastered the material being trained, then the next step for each group is assigned to disseminate knowledge from the results of the workshop to their peers in the closest school to the school where they teach.

Keywords: CAI-Contextual, Mathematics

$\begin{array}{ll}\text { History: } & \\ \text { Received } & \text { : August 02, } 2021 \\ \text { Revised } & \text { : August 03, } 2021 \\ \text { Accepted } & \text { : August 20, } 2021 \\ \text { Published } & \text { : August 25, } 2021\end{array}$




\section{INTRODUCTION}

Era globalisasi telah memunculkan kecenderungan-kecenderungan masa depan yang menuntut persaingan, hal ini membutuhkan kemampuan daya saing dan kolaborasi yang kuat. Indonesia juga terikat komitmen global (MDG, MEA, EFA, education for all, human right foreducation, education for sustainable development, competency standards, world climate, dan sebagainya). Di Indonesia, sebaran umur siswa SD pada umunya antara 7 s.d 13 tahun. Menurut teori perkembangan mental dari Jean Piaget sebaran umur tersebut berada pada tahap operasi kongkrit. Sedangkan menurut teori Jerome S. Bruner, sebaran usia siswa tersebut berada pada mode simbolik. Pada tahap operasi kongkrit, pada umumnya anak-anak dapat memahami operasi (logis) dengan bantuan benda-benda kongkrit. Sedangkan pada mode simbolik, siswa sudah dapat melakukan operasi mental. Jadi pada tahap operasi kongkrit anak dapat melakukan tindakan atau perbuatan mental mengenai kenyataan dalam kehidupan nyata, anak tidak perlu bantuan benda kongkrit dalam melakukan operasi (Adnan Khohar et al., 2016; Kurniasari et al., 2021; Matanari et al., 2020). Hal di atas perlu diketahui oleh guru SD yang mengajar pelajaran matematika, kemampuan apa yang sudah dimiliki anak pada tahap ini dan kemampuan apa yang belum diketahuinya. Anak-anak pada tahap operasi kongkrit dapat dikelompokan ke dalam taraf berpikir kongkrit (selalu memerlukan bantuan benda-benda kongkrit), taraf berpikir semi kongkrit (dapat mengerti bila dibantu dengan gambar benda kongkrit), taraf berfikir semi abstrak (dapat mengerti dengan bantuan diagram, torus, dan semacamnya), dan taraf berpikir abstrak (dapat mengerti tanpa bantuan benda-benda nyata maupun gambarnya).

Hal ini menunjukkan bahwa dalam penanaman konsep matematika terhadap siswa SD dimulai dengan benda-benda konkrit kemudian konsep itu diajarkan kembali dengan bentuk pemahaman yang lebih abstrak dengan menggunakan notasi yang lebih umum digunakan dalam matematika. Jadi, dalam pembelajaran matematika, terutama untuk kelas rendah diperlukan tahapan mulai dari tingkat konsep-pengaitan-simbol. Guru SD perlu dibekali pengetahuan tentang kesiapan siswa SD menerima pelajaran matematika. Hal ini dapat dilakukan melalui pengembangan keprofesian berkelanjutan (PKB). PKB guru terdiri atas 3 (tiga) kelompok kegiatan, yaitu pengembangan diri, publikasi ilmiah, dan karya inovatif. Kegiatan pengembangan diri bertujuan untuk meningkatkan kompetensi "apa". Kegiatan publikasi ilmiah untuk memenuhi kegiatan memperbaiki proses pembelajaran, dan kegiatan karya inovatif bertujuan untuk menerapkan kompetensi sehubungan dengan penggunaan media dan atau alat dalam pembelajaran. Porsi ketiga kegiatan bervariasi pada masing-masing jenjang kepangkatan guru. Harapan para pengambil kebijakan adalah guru dapat mulai mengembangkan profesi dari guru golongan III/a. Jika guru telah dibiasakan melakukan sejak dini, maka guru profesional lebih mudah diwujudkan. Kegiatan PKB meningkat sesuai dengan jenjang kepangkatan. Semakin tinggi jenjang kepangkatan guru, maka semakin besar pula tuntutan kepada guru tersebut mengikuti kegiatan pengembangan diri. Selain itu, untuk kegiatan publikasi ilmiah dan karya inovatif, tuntutan melakukannya yang meliputi macam dan lingkup juga semakin tinggi.

Melalui PKB, diharapkan bangsa Indonesia memiliki kemampuan penguasaan teknologi dan inovasi guna memiliki daya saing yang tinggi sehingga menjadi negara yang berkembang dan maju (developed countries). Untuk menuju negara yang berkembang, Kemenristekdikti dan Kemendes PDTT (2017) telah menjalin berbagai program dari Perguruan Tinggi untuk desa, seperti Kuliah Kerja Nyata Mahasiswa di Pedesaan, bantuan Teknologi Tepat Guna untuk desa dan lain sebagainya. Berdasarkan hasil wawancara dan pengamatan pada guru-guru SD di Kecamatan Cisurupan Kabupaten Garut, pada umumnya guru-guru tersebut masih melaksanakan pembelajaran secara konvensial dan tidak memanfaatkan multimedia secara optimal. Hal ini dikarenakan guru-guru SD di Kecamatan Cisurupan Kabupaten Garut pada umumnya tidak memiliki pengetahuan dan keterampilan 
mengembangkan pembelajaran berbasis multimedia, seperti mengoperasikan komputer atau laptop, membuat bahan ajar berbasis multimedia, penyampaian materi pelajaran menggunakan multimedia, dan melaksanakan evaluasi pembelajaran berbasis komputer. Dari beberapa guru SD tersebut, salah satu penyebabnya adalah tidak memiliki keterampilan pembelajaran berbasis komputer, sehingga jika guru-guru harus melakukan pembelajaran berbasis komputer, maka mereka tidak memiliki kesanggupan untuk melaksanakannya. Selain itu, guru-guru SD di Kecamatan Cisurupan Kabupaten Garut juga lemah mengaitkan konteks kehidupan seharihari ke dalam konten pembelajaran (khususnya dalam pembelajaran matematika). Sehingga pembelajaran menjadi kurang bermakna, siswa kurang menyadari bahwa matematika diangkat dari kehidupan sehari-hari untuk memecahkan masalah dalam kehidupan sehari-hari. Hal ini tampak pada foto-foto pembelajaran di SD-SD yang ada di lingkungan PGRI Cabang Kecamatan Cisurupan sebagai berikut.

Melihat kenyataan guru-guru tersebut tidak memiliki keterampilan melaksanakan pembelajaran berbasis komputer dan mengaitkan konteks kehidupan ke dalam konten materi pelajaran, dikarenakan mereka tidak memiliki kesempatan untuk mengembangkan pengetahuannya yang diakaibatkan oleh keterbatasan dana atau jarangnya mengikuti pelatihan pengembangan pembelajaran berbasis komputer dengan mengaitkan materi pelajaran dengan kehidupan sehari-hari, penulis menganggap perlu bahwa diadakan pengabdian masyarakat dari perguruan tinggi sebagai pengembang bahan ajar berbasis komputer guna meningkatkan keterampilan guru SD dengan tidak membayar, karena ada pihak yang mau mendanainya (seperti Tim Pengabdian pada Masyarakat Perguruan Tinggi). Dengan adanya pelatihan pembelajaran matematika berbasis komputer untuk membantu guru-guru SD agar memiliki keterampilan mengajar berbasis komputer diharapkan guru-guru SD dapat meningkatkan kompetensi berpikir matematika dan karakter siswa. Selain itu, diharapkan guru-guru SD di Kecamatan Cisurupan Kabupaten Garut dapat mengembangkan hasil pelatihan tersebut di dalam kelompok kerja guru (KKG) khusus untuk pelajaran matematika dengan teman sejawatnya.

Secara kualitas pelaksanaan pembelajaran matematika di SD Kecamatan Cisurupan Kabupaten Garut, khususnya yang dilaksanakan oleh guru-guru dalam pelajaran matematika di SD Cisurupan Kabupaten Garut, berdasarkan hasil survey,pada umumnya belum menggunakan pembelajaran CAI-Kontekstual. Selain itu guru-guru tersebut jarang mendapat pelatihan pengembangan pembelajaran matematika berbasis komputer yang mengaitkan konteks kehidupan sehari-hari dengan konten pelajaran, yang ditunjukkan dengan rendahnya hasil belajar matematika siswa. Guru-guru SD anggotan PGRI Kecamatan Cisurupan belum terbiasa dengan teknologi pembelajaran untuk meningkatkan hasil belajar matematika, baik teknologi pembelajaran maupun teknologi di bidang administrasi pembelajaran. Mereka belum mengenal pembelajaran matematika berbasis komputer (Computer Assisted Instruction =CAI) dengan mengaitkan materi pelajaran dengan konteks kehidupan. Pentingnyapenerapan pembelajaran CAI-Kontekstual didasarkan pada hasil penelitian, bahwa pembelajaran berbasis CAI-Kontekstual dapat meningkatkan kemampuan berpikir matematik dan meningkatkan kualitas karakter mahasiswa.

Permasalahan tersebut jika dibiarkan tentu akan berdampak buruk pada pembelajaran di sekolah tersebut. Salah satu solusi yang dapat dilakukan adalah melalui pembelajaran kontekstual. Pembelajaran matematika hendaknya dimulai dengan pengenalan masalah yang sesuai dengan situasi (contextual problem) (Gitriani et al., 2018; Purwanto \& Rizki, 2015; Sulistyawati, 2020). Pembelajaran matematika yang dimulai dengan pengenalan masalah yang sesuai dengan situasi dinamakan pembelajaran kontekstual, yaitu suatu konsep tentang pembelajaran yang membantu guru-guru untuk menghubungkan isi bahan ajar dengan situasisituasi dunia nyata serta penerapannya dalam kehidupan mereka sebagai anggota keluarga dan warga negara terlibat aktif dalam kegiatan belajar yang dituntut dalam pelajaran (Oktapiani \& 
Rustini, 2016; Putri et al., 2020; Simbolon \& Tapilouw, 2015). Tugas guru dalam kelas kontekstual ini adalah membantu peserta didik mencapai tujuannya, maksudnya guru lebih banyak berurusan dengan strategi daripadapenyampaian informasi (Rizwan, 2016; Ronggowulan, 2018). Tugas guru mengelola kelas sebagai sebuah tim yang bekerja sama untuk menemukan sesuatu yang baru bagi peserta didik.

Beberapa pengabdian yang sejalan dengan pengabdian ini seperti yang dilakukan oleh (Rinjani et al., 2020) menyatakan bahwa pelatihan pada guru dapat menjadi solusi untuk mempermudah penyampaian materi rajut pada anak anak sekolah dsar dalam jangka waktu yang lama. Kemudian pengabdian yang dilakukan oleh (Goenawan \& Wijayanti, 20018) menyatakan bahwa pemahaman guru tentang pelatihan berada pada tingkat yang cukup, mereka telah menerapkan metode ini kepada siswa di kelas, dan penguasaan siswa terhadap metode ini dapat dibuktikan dari kecepatan dan ketepatan saat kompetisi. Pengabdian lainnya juga dilakukan dan menyatakan bahwa pelatihan yang dilakukan telah dapat meningkatkan kompetensi guru dalam mengembangkan bahan ajar berbasis kontekstual berdasarkan kurikulum 2013 (Dwiridal \& Sari, 2021). Pengabdian Program Kemitraan Masyarakat Stimulus (PKMS) ini bertujuan untuk meningkatkan kompetensi profesional guru secara berkelanjutan melalui pelatihan cara menyusun perangkat pembelajaran bagi guru-guru Sekolah Dasar.

\section{MATERIALS AND METHODS}

Pelaksanaan kegiatan ini diselenggarakan di tiga tempat Kelompok/Rayon, masingmasing kelompok mendapatkan pelatihan sebanyak 4 kali. Kegiatan pelatihan berjalan dengan lancar dihadiri oleh 45 peserta yang dari 60 undangan (masing-masing kelompok antara 10 sampai 15 guru). Metode pelaksanaan kegiatan mengadopsi pola pelaksanaan penelitian tindakan meliputi tiga tahapan kegiatan yaitu persiapan, pelaksanaan, dan evaluasi. Persiapan dilakukan dengan melakukan survey pendahuluan untuk melihat kondisi di lapangan mengenai pengembangan profesi guru. Pelaksanaan dilakukan dengan pelatihan, menggunakan metode ceramah yaitu dengan teknik presentasi, dilanjutkan dengan diskusi disertai tanya jawab dan latihan sebagai bentuk kegiatan workshop penyusunan perangkat pembelajaran sebagai betuk pengembangan karya profesi guru. Evaluasi kegiatan dilakukan untuk masing-masing tahap dengan mengumpulkan dan menyimpulkan data dari masing-masing tahapan kegiatan. Kegiatan ini menggunakan metode ceramah dengan teknik presentasi materi perangkat pembelajaran CAI-Kontekstual dilanjutkan dengan diskusi, sedang masalah kemampuan menyusun perangkat pembelajaran CAI-Kontekstual bagi guru-guru SD diselesaikan dengan memberikan pelatihan penyusunan perangkat pembelajaran CAI-Kontekstual. Kegiatan ini dikemas dalam bentuk workshop. Sasaran PKMS ini adalah guru-guru SD anggota PGRI Kecamatan Cisurupan Kabupaten Garut.

\section{RESULTS AND DISCUSSION}

\section{Hasil}

Pelaksanaan kegiatan peningkatan profesionalitas guru dalam menghasilkan karya pengembangan profesi guru melalui pelatihan penyusunan perangkat pembelajaran berbasis CAI-Kontekstual dimulai bulan April s.d. Nopember 2019. Pelaksanaan kegiatan diawali dengan survey ke lokasi kegiatan dan mengurus perijinan sekaligus mengantarkan Surat Tugas dari Kepala LPM STT Garut kepada Mitra. Mitra dalam kegiatan ini adalah Guru-guru anggota PGRI Cabang Kecamatan Cisurupan Kabupaten Garut. Pelaksanaan kegiatan ini diselenggarakan di tiga tempat Kelompok/Rayon, masing-masing kelompok mendapatkan 
pelatihan sebanyak 4 kali. Pelaksanaan kegiatan dapat dilihat pada Gambar 1, Gambar 2, dan Gambar 3.
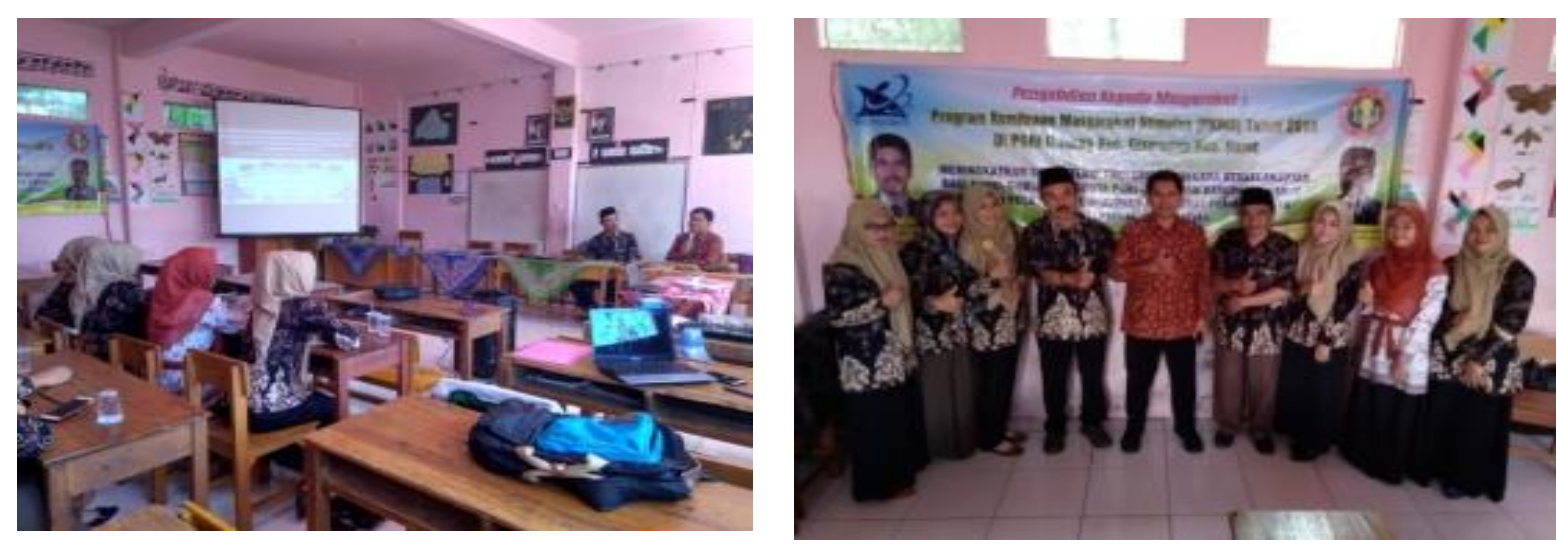

Gambar 1. Pelaksanaan Kegiatan di KKG/Rayon I
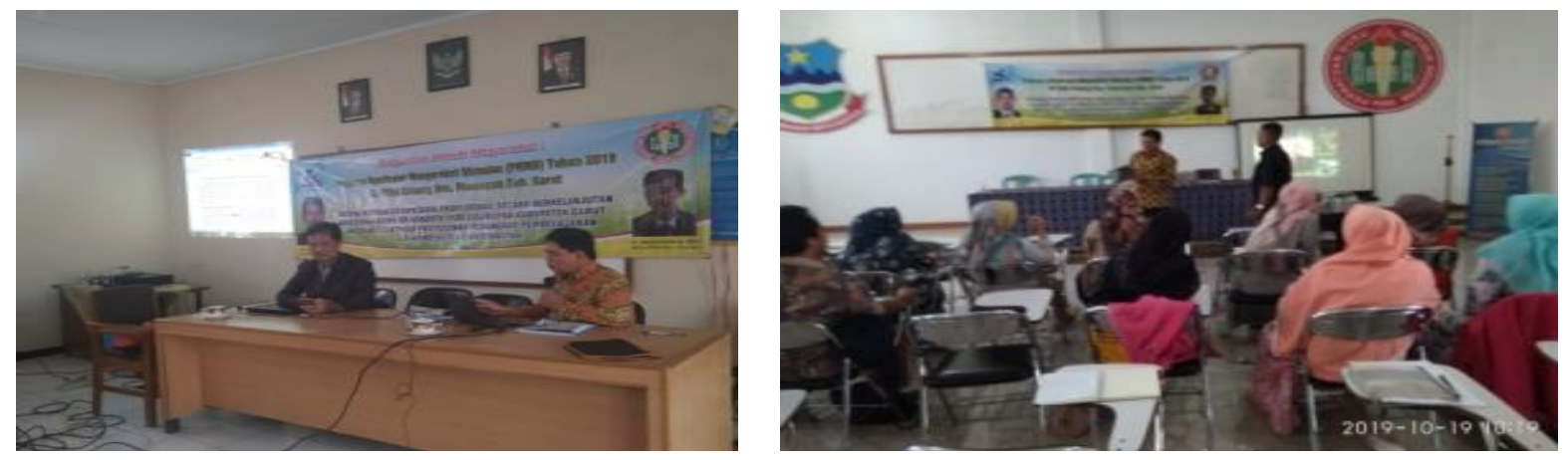

Gambar 2. Peaksanaan Kegiatan di KKG/Rayon II
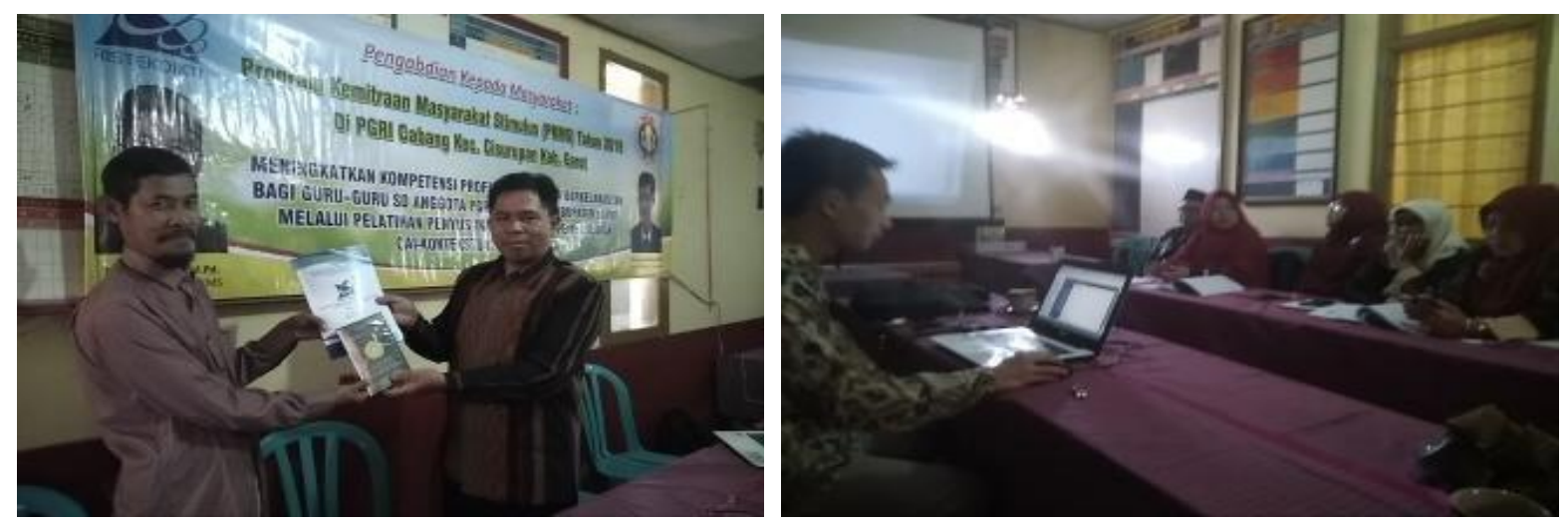

Gambar 3. Pelaksanaan Kegiatan di KKG/Rayon III

Pada pertemuan I, melalui ceramah disampaikan materi mengenai penyusunan perangkat pembelajaran matematika berbasis CAI-Kontekstual, arti penting pengembangan dan penyusunan perangkat pembelajaran matematika berbasis CAI-Kontekstual yang diberikan pada pertemuan pertama pelatihan. Pada pertemuan kedua peserta mendapatkan pelatihan cara menyusun perangkat pembelajaran matematika berbasis CAI-Kontekstual dan merancang media pembelajaran menggunakan powerpoint dan Lectora. Pada pertemuan ketiga, guru-guru berlatih menyusun sendiri perangkat pembelajaran matematika berbasis CAI-Kontekstual beserta media pembelajarannya. Pada pertemuan ke empat, guru-guru secara berkolaborasi mengimplementasikan perangkat pembelajaran yang telah disusunnya melalui 
peerteaching, yaitu mengajar teman sejawat sebagai siswa. Berdasarkan hasil kegiatan dapat diidentifikasi mengenai tingkat pemahaman peserta pengabdian adalah bahwa $75 \%$ peserta pengabdian memahami dan mampu menyusun perangkat pembelajaran matematika berbasis CAI-Kontekstual beserta media pembelajarannya. Hasil yang terkumpul penyusunan perangkat pembelajaran matematika berbasis CAI-Kontekstual 3 perangkat dari 3 kelompok (masing-masing kelompok menghasilkan perangkat pembelajaran matematika berbasis CAIKontekstual). Sebelum pelaksanaan kegiatan PKMS kepada guru-guru anggota PGRI Cabang Kecamatan Cisurupan Kabupaten Garut, diperoleh data profesionalitas mitra.

Tabel 1. Permasalahan Mitra Sebelum Kegiatan

\begin{tabular}{clcc}
\hline No. & \multicolumn{1}{c}{ Jenis Kegiatan Yang Dilakukan Mitra } & $\%$ & Keterangan \\
\hline 1. & $\begin{array}{l}\text { Banyaknya Kelompok Kerja Guru (KKG) yang mengkaji } \\
\text { pembelajaran CAI-Kontekstual }\end{array}$ & 0 & Tidak ada \\
2. & $\begin{array}{l}\text { Guru-guru yang memiliki pengetahuan pembelajaran CAI- } \\
\text { Kontekstual }\end{array}$ & 3 & Sedikit \\
3. & $\begin{array}{l}\text { Guru-guru yang menyusun rencana pembelajaran CAI- } \\
\text { Kontekstual }\end{array}$ & 3 & Sedikit \\
4. $\begin{array}{l}\text { Guru-guru yang membuat media pembelajaran berbasis } \\
\text { CAI-Kontekstual }\end{array}$ & 2 & Sedikit \\
5. Kontekuru melaksanakan pembelajaran berbasis CAI- & 5 & Sedikit \\
\hline
\end{tabular}

Sumber: PGRI Cabang Kec. Cisurupan Kab. Garut Prov. Jawa Barat

Setelah pelaksanaan kegiatan PKMS kepada guru-guru anggota PGRI Cabang Kecamatan Cisurupan Kabupaten Garut, diperoleh data profesionalitas mitra. Kegiatan mitra setelah pelaksanaan PKMS dapat dilihat pada Tabel 2. Terdapat juga peningkatan profesionalitas mitra yang dapat dilihat pada Tabel 3.

Tabel 2. Kegiatan Mitra Setelah Pelaksanaan PKMS

\begin{tabular}{clcc}
\hline No. & \multicolumn{1}{c}{ Jenis Kegiatan Yang Dilakukan Mitra } & $\%$ & Keterangan \\
\hline 1. & $\begin{array}{l}\text { Banyaknya Kelompok Kerja Guru (KKG) yang mengkaji } \\
\text { pembelajaran CAI-Kontekstual }\end{array}$ & 10 & Meningkat \\
2. & $\begin{array}{l}\text { Guru-guru yang memiliki pengetahuan pembelajaran CAI- } \\
\text { Kontekstual }\end{array}$ & 20 & Meningkat \\
3. & $\begin{array}{l}\text { Guru-guru yang menyusun rencana pembelajaran CAI- } \\
\text { Kontekstual }\end{array}$ & 15 & Meningkat \\
4. $\begin{array}{l}\text { Guru-guru yang membuat media pembelajaran berbasis } \\
\text { CAI-Kontekstual }\end{array}$ & 15 & Meningkat \\
5uru-guru melaksanakan pembelajaran berbasis CAI- & 15 & Meningkat \\
\hline
\end{tabular}

Tabel 3. Peningkatan Profesionalitas Mitra

\begin{tabular}{clcccc}
\hline No. & $\begin{array}{c}\text { Jenis Kegiatan Yang Dilakukan } \\
\text { Mitra }\end{array}$ & $\begin{array}{c}\text { Sebelum } \\
(\boldsymbol{\%})\end{array}$ & $\begin{array}{c}\text { Sesudah } \\
(\boldsymbol{\%})\end{array}$ & $\mathbf{g}(\boldsymbol{\%})$ & Kriteria \\
\hline 1. & $\begin{array}{l}\text { Banyaknya Kelompok Kerja Guru } \\
\text { (KKG) yang mengkaji pembelajaran }\end{array}$ & 0 & 10 & 10 & Sedang \\
& \begin{tabular}{l} 
CAI-Kontekstual \\
\hline
\end{tabular}
\end{tabular}




\begin{tabular}{clcccc}
\hline No. & $\begin{array}{c}\text { Jenis Kegiatan Yang Dilakukan } \\
\text { Mitra }\end{array}$ & $\begin{array}{c}\text { Sebelum } \\
(\boldsymbol{\%})\end{array}$ & $\begin{array}{c}\text { Sesudah } \\
(\%)\end{array}$ & g (\%) & Kriteria \\
\hline 2. $\quad \begin{array}{l}\text { Guru-guru yang memiliki } \\
\text { pengetahuan pembelajaran CAI- } \\
\text { Kontekstual }\end{array}$ & 3 & 20 & 17 & Tinggi \\
3. $\begin{array}{l}\text { Guru-guru yang menyusun rencana } \\
\text { pembelajaran CAI-Kontekstual }\end{array}$ & 3 & 15 & 12 & Sedang \\
$\begin{array}{l}\text { Guru-guru yang membuat media } \\
\text { pembelajaran berbasis CAI- }\end{array}$ & 2 & 15 & 13 & Sedang \\
$\begin{array}{l}\text { Kontekstual } \\
\text { Guru-guru melaksanakan } \\
\text { pembelajaran berbasis CAI- }\end{array}$ & 5 & 15 & 10 & Sedang \\
Kontekstual & & & & \\
\hline
\end{tabular}

Dalam melakukan pelatihan dalam bentuk workshop penyusunan perangkat pembelajaran matematika SD berbasis CAI-Kontekstual, Tim pelaksana pengabdi STT Garut didukung oleh fasilitas pendukung berupa alat transportasi, alat komunikasi, kelengkapan ATK dan akses internet untuk mempermudah pelaksanaan workshop. Kegiatan workshop tersebut sepenuhnya dibiayai oleh Dana Hibah PKMS dari Direktorat Riset dan Pengabdian Masyarakat (DRPM) Direktorat Jenderal Riset dan Pengembangan Kementerian Riset, Teknologi, dan Pendidikan Tinggi Tahun 2019 dengan Nomor Kontrak: 2874/L4/PP/ 2019. Sedangkan pihak kampus STT Garut dan Mitra guru-guru anggota PGRI Cabang Kec. Cisurupan Kab. Garut tidak menyediakan dana kegiatan PKMS. Untuk memperlancar kegiatan PKMS ini, pihak kampus STT Garut menyediakan laboratorium komputer, laboratorium multimedia, dan laboratorium micro teaching, sebagai pendampingan di lapangan. Tim pelaksana sendiri memiliki kualifikasi sesuai dengan bidangnya. Hal ini dapat dilihat pada Gambar 4.
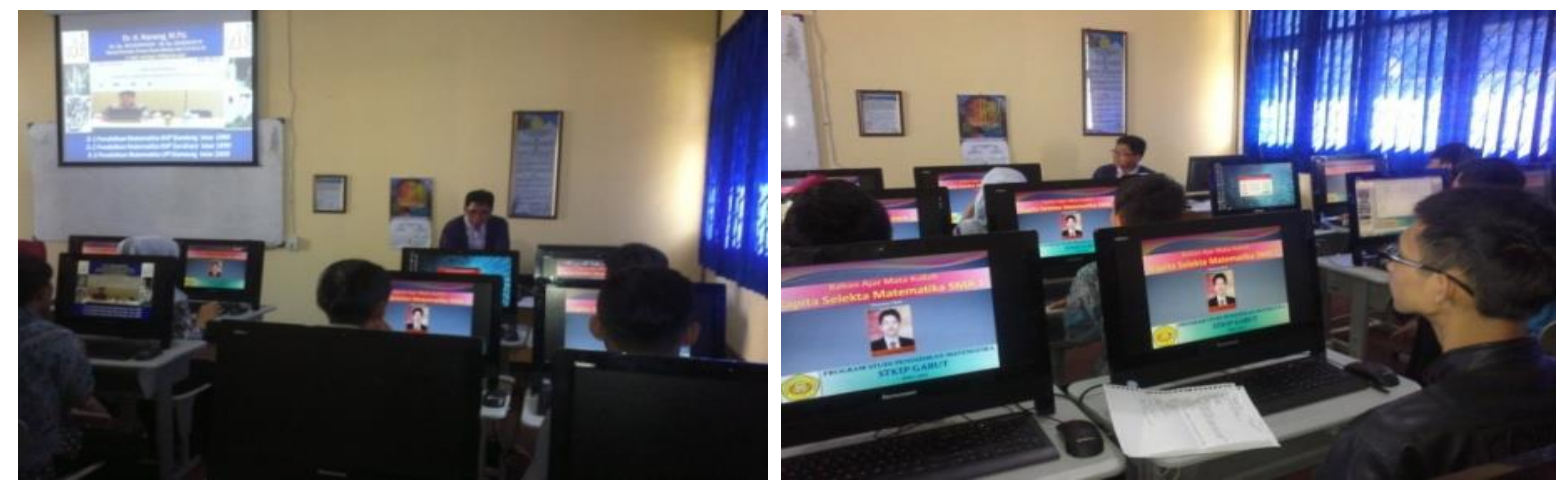

Gambar 4. Pelaksanaan Pembelajaran CAI-Kontekstual di Lab Komputer

Kegiatan pelatihan ini pun dapat berjalan dengan lancar dikarenakan antusiasme peserta untuk memahami perangkat pembelajaran CAI-Kontekstual, arti penting perangkat pembelajaran CAI-Kontekstual, arti penting peningkatan kualitas dan kuantitas perangkat pembelajaran CAI-Kontekstual di SD. Kemauan dari peserta pengabdian untuk menyusun perangkat pembelajaran CAI-Kontekstual. Antusisme dibuktikan dengan banyaknya pertanyaan yang muncul ketika pelaksanaan diskusi kelompok, pengerjaan tugas yaitu penyusunan perangkat pembelajaran CAI-Kontekstual, serta tidak adanya peserta yang membolos selama pelatihan. Tahapan pelaksanaan pengabdian yang sudah dilakukan sampai saat ini adalah pada tahapan pelatihan guru/peserta dalam penyusunan perangkat pembelajaran matematika berbasis CAI-Kontekstual beserta media pembelajarannya. Hasil yang diharapkan pada tahap ini adalah guru mengenal dan mampu menyusun perangkat pembelajaran 
matematika berbasis CAI-Kontekstual beserta media pembelajarannya menggunakan powerpoint dan Lectora. Pada tahapan selanjutnya adalah pendampingan guru dalam menyempurnakan menyusun perangkat pembelajaran matematika berbasis CAI-Kontekstual beserta media pembelajarannya. Hasil penyempurnaan penyusunan perangkat pembelajaran matematika berbasis CAI-Kontekstual tersebut disajikan pada acara lokakarya oleh perwakilan masing-masing kelompok. Bentuk penyajian berupa peer teaching. Selanjutnya diadakan evaluasi tentang kelebihan dan kelemahan implementasi perangkat pembelajaran matematika berbasis CAI-Kontekstual (Divayana \& Sugiharni, 2016). Apabila berdasarkan hasil evaluasi dari masing-masing kelompok/rayon, dipandang peserta workshop telah menguasai materi yang dilatihkan, maka langkah selanjutnya masing-masing kelompok tersebut ditugaskan untuk menyebarkan pengetahuan dari hasil workshop keteman sejawatnya yang ada di sekolah terdekat dengan sekolah tempat mengajarnya.

Pembelajaran matematika yang dimulai dengan pengenalan masalah yang sesuai dengan situasi dinamakan pembelajaran kontekstual, yaitu suatu konsep tentang pembelajaran yang membantu guru-guru untuk menghubungkan isi bahan ajar dengan situasi-situasi dunia nyata serta penerapannya dalam kehidupan mereka sebagai anggota keluarga dan warga negara terlibat aktif dalam kegiatan belajar yang dituntut dalam pelajaran (Oktapiani \& Rustini, 2016; Putri et al., 2020; Simbolon \& Tapilouw, 2015). Tugas guru dalam kelas kontekstual ini adalah membantu peserta didik mencapai tujuannya, maksudnya guru lebih banyak berurusan dengan strategi daripadapenyampaian informasi (Rizwan, 2016; Ronggowulan, 2018). Tugas guru mengelola kelas sebagai sebuah tim yang bekerja sama untuk menemukan sesuatu yang baru bagi peserta didik.

\section{CONCLUSION}

Kegiatan pengabdian Program Kemitraan Masyarakat Stimulus (PKMS) sudah dilakukan berupa pelatihan perangkat pembelajaran matematika berbasis CAI-Kontekstual beserta menyusun media pembelajarannya. Dari hasil diskusi dengan Ketua PGRI Cabang Kecamatan Cisurupan dan guru-guru anggota PGRI sebagai peserta pelatihan, mulai dari awal koordinasi dan selama pelaksanaan pengabdian, mereka sangat mengharapkan pelatihanpelatihan seperti penyusunan perangkat pembelajaran matematika berbasis CAI-Kontekstual beserta media pembelajarannya guna melakukan visualisasi objek-objek matematika. Berdasarkan hasil evaluasi dari masing-masing kelompok/rayon, dipandang peserta workshop telah menguasai materi yang dilatihkan, maka langkah selanjutnya masing-masing kelompok tersebut ditugaskan untuk menyebarkan pengetahuan dari hasil workshop keteman sejawatnya yang ada di sekolah terdekat dengan sekolah tempat mengajarnya.

\section{REFERENCES}

Adnan Khohar, M., Ruminiati, \& Munzil. (2016). Penerapan Teams Games Tournament Untuk Meningkatkan Hasil Belajar IPS Kelas IV SDN Blabak 1 Kandat Kediri. Jurnal Pendidikan: Teori , Penelitian Dan Pengembangan, 1(9), 1869-1873. https://doi.org/http://dx.doi.org/10.17977/jp.v1i9.6864.

Divayana, D. G. H., \& Sugiharni, G. A. D. (2016). Evaluasi program sertifikasi komputer pada universitas teknologi Indonesia menggunakanmodel cse-ucla. JPI (Jurnal Pendidikan Indonesia), 5(2), 158. https://doi.org/10.23887/jpi-undiksha.v5i2.8586.

Dwiridal, L., \& Sari, S. Y. (2021). Peningkatan Kompetensi Guru-Guru IPA SMP / MTsN Lubuk Sikaping melalui Pelatihan Pengembangan Bahan Ajar Berbasis Kontekstual. Jurnal Pengabdian Pada Masyarakat, 6(1), 170-177. https://doi.org/10.30653/002.202161.502. 
Gitriani, R., Aisah, S., Hendriana, H., \& Herdiman, I. (2018). Pengembangan Lembar Kerja Siswa Berbasis Pendekatan Kontekstual pada Materi Lingkaran Untuk Siswa SMP. Jurnal Review Pembelajaran Matematika, 3(1), 40-48. https://doi.org/10.15642/jrpm.2018.3.1.40-48.

Goenawan, S. I., \& Wijayanti, S. H. (20018). Peningkatan Kemampuan Berhitung Metris Di Sekolah Dasar Negeri Sekecamatan Cisauk, Tangerang. Jurnal Abdimas, 22(2), 227234. https://journal.unnes.ac.id/nju/index.php/abdimas/article/view/8983.

Kurniasari, M., Amin, S. M., \& Wiryanto, W. (2021). Pengembangan Media Pembelajaran Matematika Kuperan dan Baperan Untuk Pembelajaran Number Sense. Jurnal Pendidikan Matematika, 12(2), 207-220. https://doi.org/10.36709/jpm.v12i2.19862.

Matanari, C., Gaol, R. L., \& Simarmata, E. (2020). Hubungan Pendidikan Karakter Terhadap Perkembangan Sosial Anak Sekolah Dasar. Journal of Educational Review and Research, 6(2), 294-300. https://doi.org/https://doi.org/10.31949/educatio.v6i2.435.

Oktapiani, R., \& Rustini, T. (2016). Contextual Teaching And Learning (CTL) Untuk Meningkatkan Kreativitas Berpendapat Siswa Pada Pembelajaran IPS. EduHumaniora | Jurnal Pendidikan Dasar Kampus Cibiru, 5(2), 121-127. https://doi.org/10.17509/eh.v5i2.2843.

Purwanto, Y., \& Rizki, S. (2015). Pengembangan Bahan Ajar Berbasis Kontekstual Pada Materi Himpunan Berbantu Video Pembelajaran. AKSIOMA Journal of Mathematics Education, 4(1), 67-77. https://doi.org/10.24127/ajpm.v4i1.95.

Putri, Y. U., Musdi, E., Permana, D., \& Yerizon, Y. (2020). Efektivitas Perangkat Pembelajaran Matematika Berbasis Pendekatan Contextual Teaching and Learning Terhadap Kemampuan Komunikasi Matematis. AKSIOMA: Jurnal Program Studi Pendidikan Matematika, 9(1), 205. https://doi.org/10.24127/ajpm.v9i1.2305.

Rinjani, D., Sari, M. P., \& Permana, F. C. (2020). Pelatihan Teknik Merajut terhadap Guru Kelas 1 dan 2 Sekolah Dasar menggunakan Media Pembelajaran berupa Video Tutorial. Jurnal Pengabdian Pada Masyarakat, 5(3), 695-706. https://doi.org/https://doi.org/10.30653/002.202053.356.

Rizwan, R. (2016). Meningkatkan Aktivitas dan Hasil Belajar Peserta Didik dalam Belajar IPA melalui Pembelajaran Konstektual. Jurnal Educatio, 2(1), 11-20. https://doi.org/http://dx.doi.org/10.29210/12016227.

Ronggowulan, L. (2018). Pembelajaran Kontekstual Learning dalam Strategi Adaptasi Masyarakat Terhadap Bencna Abrasi Pada Materi Mitigasi Bencana di Kelas X IPS SMA Negeri 1 Kragan. Jurnal Kependidikan Dasar Islam Berbasis Sains, 3(2). https://doi.org/https://doi.org/10.21154/ibriez.v3i2.57.

Simbolon, E. R., \& Tapilouw, F. S. (2015). Pengaruh Pembelajaran Berbasis Masalah Dan Pembelajaran Kontekstual Terhadap Berpikir Kritis Siswa Smp. Edusains, 7(1), 97104. https://doi.org/10.15408/es.v7i1.1533.

Sulistyawati, E. (2020). Keefektifan pendekatan kontekstual berbasis budaya lokal ditinjau dari prestasi, minat belajar, dan apresiasi terhadap matematika. Jurnal Penelitian Pendidikan Dan Pengajaran Matematika, 6(1), 27-42. https://doi.org/https://doi.org/10.37058/jp3m.v6i1.1421. 